\title{
Developing Indicators of Green Initiation and Green Design of Green Supply Chain Management in Construction Industry
}

\author{
Mochamad Agung Wibowo ${ }^{1 *}$, Naniek Utami Handayani ${ }^{2}$, Nur Farida $^{2}$, Asri Nurdiana ${ }^{3}$ \\ ${ }^{1}$ Department of Civil Engineering, Faculty of Engineering, Diponegoro University, Indonesia \\ ${ }^{2}$ Department of Industrial Engineering, Faculty of Engineering, Diponegoro University, Indonesia \\ ${ }^{3}$ Study Program of Civil Engineering, Vocational School, Diponegoro University, Indonesia
}

\begin{abstract}
Project is a set of interrelated activities and requires skills from different professions, and also project is involved the various of stakeholders in each phase of the Project Life Cycle. Implementation of Green Supply Chain in construction projects meant to bring the concept of eco-friendly in every process from the initiation phase, planning phase, the construction phase, and the operation and maintenance phase. It is necessary to identify indicators of green initiation and green design and how to explain the relationship between the role of initiation by the owner and the design process by a design consultant. This study aims to identify the indicators of green initiation and green design concept as part of Green Supply Chain. The method used for this study is a descriptive research that identifies and develop a framework for implementing green initiation and green design in construction industry that consists of concept, dimensions, elements, and indicators. GSCM in construction projects was determined by 9 indicators in the green initiation phase and 40 indicators in the green design phase. The success of green concept in construction project is very determined from these two phases as the beginning of the process, and the most important parties are the owners and design consultants.
\end{abstract}

\section{Introduction}

The construction industry has an impact on the environment in the form of natural resources used and solid waste produced, and they can damage the surrounding environment [1]. The previous research states that the sheer number of solid waste generated by the construction is $20-30 \%$ of construction projects in Brazil, and $1-10 \%$ in the Netherlands [2]. To anticipate the issues related to environmental impacts, it is necessary to use waste management as part of the construction project management [3].

On the other hand, the employee of construction project should also pay attention to Supply Chain management that is an activity or a network of cooperation related to one another to create and distribute goods or services [4]. In construction project, the proper of supply chain management is very influential on performance improvement project [5]. The construction project is often improvidence (waste) in the form of activities that use resources but do not produce any value [5]. The concept of waste reduction in construction projects is called lean construction. Supply Chain Management (SCM) is closely related to avoid construction waste [5], so SCM can support lean construction on the construction project.

Implementation of Green Supply Chain concept in construction projects need to be studied in order to create a lean construction that is friendly to the environment.
This is evident from the development of the concept of Green Building and Green Construction. In manufacturing, Green Supply Chain Management (GSCM) is defined as a purchase, process, materials management, distribution, and marketing with environmentally friendly, and also reverse logistics $[4,6$, 7]. The purpose of the green supply chain is to consider the environmental impact caused by the production process. Implementation of Green Supply Chain in construction projects meant to bring the concept of ecofriendly in every process from the initiation phase, planning phase, the construction phase, and the operation and maintenance phase [8].

Researches related to GSCM in the field of construction projects was adopted from the successful implementation of GSCM in the manufacturing industry. Based on previous studies, the GSCM concept consists of Green Products Design, Green Material Management, Green Manufacturing, Green Distribution and Marketing, and Reverse Logistics [9]. The concept of Green Practices was built by Green Procurement, Green Manufacturing, Green, Distribution, and Green Logistics [10]. GSCM practices into five categories, i.e. intraorganizational environment management, product ecodesign, green supplier integration, green customer cooperation, reverse logistics [11]. Meanwhile, in the construction industry research field, the GSCM concept consists of Green building design, Green purchasing, Green transportation, Green construction, and End-of-life

Corresponding author: agung.wibowo@ft.undip.ac.id 
management [5]. The concept of green practices includes green purchase, green production, green logistics, and reuse [12]. On the other hand, regulating the green concepts from the beginning of the construction process is important, because the green concept can be realized if there is a continuity in each project life cycle. That is, the concept of green construction cannot be applied to each phase separately, the green concept is a unit that must be designed from the initiation phase. Every phase in project life cycle is interact with each other [13]. Life cycle of a project includes the following phases: initiation planning and feasibility studies, design and engineering, construction, and operation and maintenance [14].

In the construction industry, the design process cannot be separated by the initiative of the project owner. The design idea of a project is always started by the owner, so every detail of the design must involve an agreement between the owner and the consultant of design. It is necessary to identify indicators of green initiation and green design and how to explain the relationship between the role of initiation by the owner and the design process by a design consultant. This study aims to identify the indicators of green initiation and green design concept as part of Green Supply Chain.

\section{Project Life Cycle}

Construction projects are some activities that have complex and diverse properties. To overcome difficulties in managing and coordinating, the project is divided into several stages from beginning to end, known as Project Life Cycle (PLC). In general, PLCs consist of several phases: initiation / conceptualization, planning, implementation, and operation / maintenance $[14,15,16]$. This term is usually modified based on the project area, as presented in Fig. 1. Projects in the construction industry are temporary and follow the life cycle of a particular project. In the traditional management model, all of these stages are less coordinated with each other. This is one reason why the construction industry is much segmented.

The initiation phase involves owner as key stakeholders in the process. The initiation phase needs assessment, data collection, surveys, and feasibility studies. Feasibility studies are taken at the beginning of the construction project to decide whether a project is feasible. In addition, a feasibility study was also conducted to determine alternative possibilities and assist in the development of supporting project documents. The whole process will then be developed as a project proposal $[17,18,19]$.

Furthermore, the planning phase will produce project planning documents commonly known as work plans (eg. Detail Engineering Design (DED), Work Breakdown Structure (WBS), Gantt Chart, PERT) and other planning documents (eg. quality / specification, risk management). The construction phase is the execution process which includes execution of plans, project resource management, monitoring, and reporting. In a traditional perspective, the construction phase is the overall focus of the PLC, while greater influence actually comes from the operational and maintenance phases. The operational and maintenance phases can show the success of the project which usually also consists of evaluation and assessment after completion of the project $[14,15,16]$.

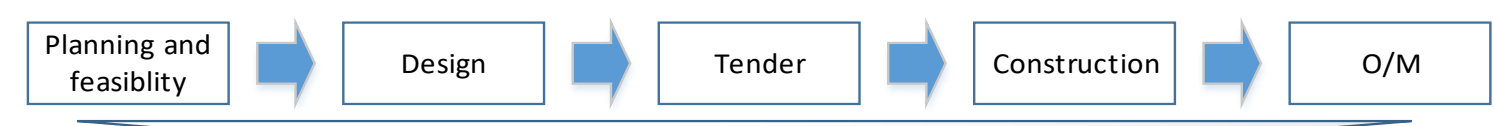

\begin{tabular}{|l||l|}
\hline $\begin{array}{l}\text { - Financial } \\
\text { analysis }\end{array}$ & $\begin{array}{l}\text { - Management } \\
\text { and } \\
\text { coordination of } \\
\text { Formulation of } \\
\text { the preliminary } \\
\text { budgets } \\
\text { the progress of } \\
\text { - Feasibility study } \\
\text { report }\end{array}$ \\
- others & $\begin{array}{l}\text { Tesign } \\
\text { strategy } \\
\text { others }\end{array}$ \\
\hline
\end{tabular}

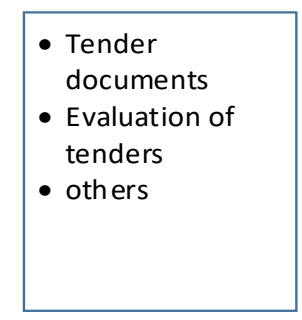

- Maintenance or
operational
manuals
- Acceptance and
transfer of
project
- others

Fig. 1 Project Life Cycle

\section{Green Supply Chain Management in Construction}

GSCM implementation plays significant roles for manufacturers. Many studies have been conducted to prove the success of GSCM application in the manufacture scope. For example, eco-design has the function of making or repairing products while reducing the environmental impact that the product makes [20]. GSCM is defined as the integration of sustainable practices into upstream and downstream SCM to bring about long-term benefits through the application of responsible environmental and social behaviour among all supply chain members $[9,21,22]$. One example of how GSCM has been applied in the construction industry is in green construction. Green construction is carried out according to the following guideline. On the premise of ensuring quality, safety and other basic requirements, scientific management and technological progress should be used in engineering construction to maximise the conservation of resources and reduce the construction activities which will bring negative impacts on the environmental, and to improve the goal of four savings (energy, land, water and materials) and environmental protection [23]. Therefore, GSCM implementation in construction practice would be an excellent way of reducing construction waste. 
In this study, the framework of Green Supply Chain Management in the construction industry is explained in detail as follow [24].

Green Initiation. Green initiation has been identified as a primary requirement for determining where developers need to design and build sustainable projects that can provide lower energy, save water consumption, and a healthy environment in their projects [25]. Green initiation closely related to project owner commitment. To achieve successful project delivery of sustainable construction project, owner commitment is the most important thing because owners are the decision maker, and the key to making a sustainable project happen in the construction industry [26]. The other factor that must be considering is the feasibility of development project. So that a feasibility study must be conducted in initiation phase. Feasibility study is the assessment for the proposed project that consists of economic assessment, financial assessment, risk assessment, social, and environmental issue. The result from this study will help the project owner to decide whether or not the project is feasible and worth to embodied [27].

Green Design. Green design is the most important phase because decisions made in the design phase will have a significant effect on the lifecycle environment of the project system. Design should become a prime deliberation for identifying any possible effects on the project regarding environmental impacts [28]. The benefit of green design concept is to diminishing the environmental impact caused by construction design and processes. Designing construction projects in environmentally friendly ways is the purpose of green design. Green design consists of two main elements, there are life cycle analysis (LCA) and environmentally conscious design (ECD). LCA is used to strengthen the construction development so that all environment negative impact from construction activity can be minimized, while ECD is used to design construction activity while protecting the environment. The Building Green US Council state that green design provides savings of up to $30 \%$ for energy, $35 \%$ for carbon, 30 $50 \%$ water usage [29]. The parts of green design are sustainable sites choices, design considerations to reduce the use of materials, design considerations to reduce the use of materials, as well as reducing and recycling water [30].

Green Materials Management. Green materials management is about the change of potentially hazardous activities or materials with more environmentally friendly ones. It is consisting of two processes, as follows: green materials procurement and green materials selection. The specification of materials selection that can be processed in green materials management include the materials used in construction, which should be easy to separate, and adaptable or useful in existing processes [9, 24].

Green Construction. Green construction has the aim to optimizing the resources conservation and reducing construction activities that have negative impacts for the environment while achieving the goal of savings in the four resource areas (energy, land, water, and materials). Resource consumption reduction, waste reduction and emissions reduction are the general concepts that are integrated to establish green construction. There are several barriers to green construction, as follows: additional costs for green construction, lack of awareness, lack of knowledge, and lack of green suppliers [23]. Several approaches have been emerged to reduce these negative features in construction. These approaches are efficient machines, separate use of waste to allow reuse / recycling and fabrication using automation [5].

Green Operation and Maintenance. Green operation and maintenance techniques consist of training, clearance, work application and control to conserve 'green' materials in the project in conforming with environmental needs $[14,31]$.

\section{Research Methodology}

The method used of this study was a descriptive research that identifies and develop a framework for implementing green initiation and green design in construction industry that consists of concept, dimensions, elements, and indicators. Data collection method that was used is observation through literature review and also interview with experts from academic, design consultants, project owner and ministry. The coverage topics of literature review that conducted was about waste management, project life cycle, and green supply chain management in construction industry.

Developing Indicators of Green Initiation in Construction Projects. Green initiation has been recognised as a main requirement for determining where developers need to design and build sustainable projects that can provide lower energy, water savings and a healthy environment in their projects [25]. Green initiation is a discussion process between owner and consultant of design about building concepts based on green because many owners do not understand about the severity of construction waste. The indicators of Green Initiation in Construction [26, 27, 32 - 35] as shown on Table 1.

Table 1 The Indicaators of Green Initiation

\begin{tabular}{|c|c|c|c|}
\hline No & Element & Indicator & Reference \\
\hline \multicolumn{4}{|c|}{ Dimension: Environment Conscious Design } \\
\hline \multirow[t]{4}{*}{1} & \multirow[t]{4}{*}{$\begin{array}{l}\text { Project } \\
\text { owner } \\
\text { commitment }\end{array}$} & $\begin{array}{l}\text { Educating project team } \\
\text { participants to achieve } \\
\text { sustainable } \\
\text { construction and } \\
\text { building concepts. }\end{array}$ & \multirow[t]{4}{*}{$\begin{array}{l}26,32,33, \\
34\end{array}$} \\
\hline & & $\begin{array}{l}\text { Provide vision } \\
\text { statement on the } \\
\text { reason to develop } \\
\text { GSCM project. }\end{array}$ & \\
\hline & & $\begin{array}{l}\text { Facilitating the } \\
\text { integration of other } \\
\text { project participants. }\end{array}$ & \\
\hline & & $\begin{array}{ll}\text { Introducing } & \text { green } \\
\text { intention early } & \end{array}$ & \\
\hline 2 & $\begin{array}{l}\text { Feasibility } \\
\text { study }\end{array}$ & $\begin{array}{lr}\text { Perform } & \text { area, } \\
\text { demographic, } & \text { and } \\
\text { neighbourhood } & \\
\end{array}$ & 27,35 \\
\hline
\end{tabular}




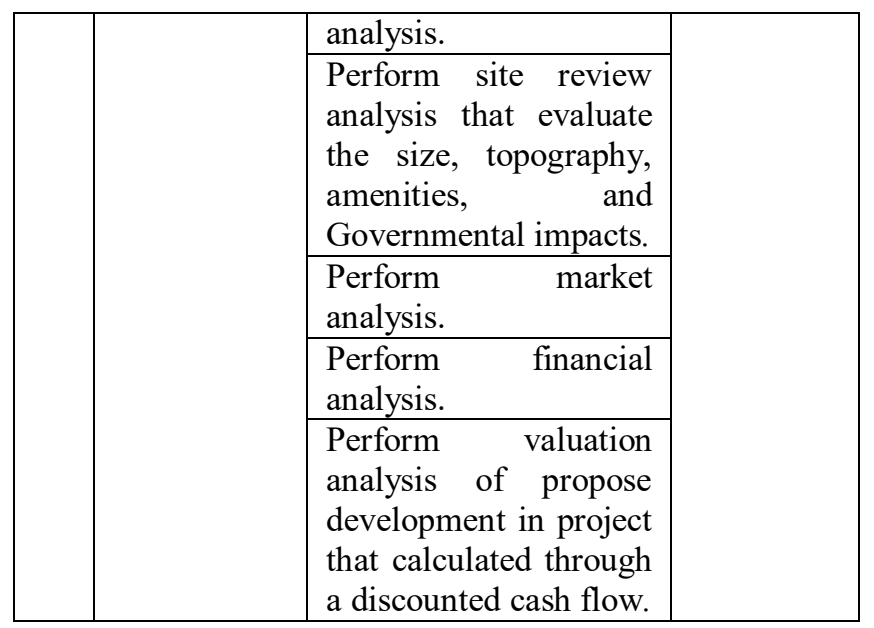

Developing Indicators of Green Design in Construction Projects. Green design is the most important phase because all decisions that made in the design phase will give significant impact to environment life cycle in the project system. Zhang, et al (2011) declare that design must become a primary consideration to identify the environmental effect that may happen to project. Green design concept benefit is reduced the environmental effect from construction design and processes. The purpose of green design is to design a construction project with environmentally friendly ways. Green design consists of two main elements, there are life cycle analysis (LCA) and environmentally conscious design (ECD). LCA is used to strengthen the construction development so that all environment negative impact from construction activity can be minimized, while ECD is used to design construction activity while protecting the environment. The indicators of Green Design in Construction [36 - 59] as shown on Table 2.

Table 2 The Indicators of Green Design

\begin{tabular}{|c|c|c|c|}
\hline No & Element & Indicator & Reference \\
\hline \multicolumn{4}{|c|}{ Dimension: Design } \\
\hline \multirow[t]{3}{*}{1} & \multirow[t]{3}{*}{$\begin{array}{l}\text { Design } \\
\text { changes }\end{array}$} & $\begin{array}{l}\text { Number of design } \\
\text { changes in a } \\
\text { project. }\end{array}$ & \multirow[t]{3}{*}{36} \\
\hline & & $\begin{array}{l}\text { Percentage of } \\
\text { additional cost due } \\
\text { to design changes. }\end{array}$ & \\
\hline & & $\begin{array}{l}\text { Percentage of } \\
\text { additional time due } \\
\text { to design changes. }\end{array}$ & \\
\hline \multirow[t]{2}{*}{2} & \multirow[t]{2}{*}{$\begin{array}{l}\text { Design and } \\
\text { detailing } \\
\text { complexity }\end{array}$} & $\begin{array}{l}\text { Detailed } \\
\text { Engineering } \\
\text { Design (DED) give } \\
\text { all the needed } \\
\text { information } \\
\text { completely. }\end{array}$ & \multirow[t]{2}{*}{37,38} \\
\hline & & $\begin{array}{l}\text { Detailed } \\
\text { Engineering } \\
\text { Design (DED) } \\
\text { content is clear, } \\
\text { easy to read, and } \\
\text { understood. }\end{array}$ & \\
\hline 3 & Design and & Doing thorough & 39,40 \\
\hline
\end{tabular}

\begin{tabular}{|c|c|c|c|}
\hline & $\begin{array}{l}\text { construction } \\
\text { detail errors }\end{array}$ & $\begin{array}{l}\text { review of all } \\
\text { design calculation } \\
\text { to avoid inadequate } \\
\text { design. }\end{array}$ & \\
\hline \multirow[t]{2}{*}{4} & \multirow[t]{2}{*}{$\begin{array}{l}\text { Unclear and } \\
\text { unsuitable } \\
\text { specification }\end{array}$} & $\begin{array}{l}\text { Specification is not } \\
\text { use awkward } \\
\text { phrases such as } \\
\text { "and/or". }\end{array}$ & \multirow[t]{2}{*}{$41,42,43$} \\
\hline & & $\begin{array}{l}\text { Specification is not } \\
\text { contain conflict } \\
\text { requirements. }\end{array}$ & \\
\hline 5 & $\begin{array}{l}\text { Poor } \\
\text { communication } \\
\text { and } \\
\text { coordination }\end{array}$ & $\begin{array}{l}\text { Joint planning } \\
\text { between designer } \\
\text { and constructor to } \\
\text { decrease design } \\
\text { inconsistence. }\end{array}$ & 44,45 \\
\hline 6 & $\begin{array}{l}\text { Prefabricated } \\
\text { use }\end{array}$ & $\begin{array}{l}\text { Use component or } \\
\text { something which } \\
\text { has been built or } \\
\text { made offsite and is } \\
\text { ready for use. }\end{array}$ & 46 \\
\hline \multicolumn{4}{|c|}{ Dimension: Innovation Capability } \\
\hline \multirow[t]{2}{*}{7} & \multirow[t]{2}{*}{$\begin{array}{l}\text { Resource } \\
\text { conservation }\end{array}$} & $\begin{array}{l}\text { Using non-toxic or } \\
\text { less toxic materials } \\
\text { in design } \\
\text { specification. }\end{array}$ & \multirow[t]{2}{*}{$47,48,49$} \\
\hline & & $\begin{array}{l}\text { Consider material } \\
\text { durability in design } \\
\text { specification. }\end{array}$ & \\
\hline \multirow[t]{3}{*}{8} & \multirow[t]{3}{*}{$\begin{array}{l}\text { Design support } \\
\text { for waste } \\
\text { management } \\
\text { implementation }\end{array}$} & $\begin{array}{l}\text { Make coordination } \\
\text { design to minimize } \\
\text { excess cutting and } \\
\text { jointing of } \\
\text { materials. }\end{array}$ & \multirow[t]{3}{*}{46} \\
\hline & & $\begin{array}{l}\text { Make design with } \\
\text { standard material } \\
\text { dimension. }\end{array}$ & \\
\hline & & $\begin{array}{l}\text { Building element } \\
\text { and material design } \\
\text { easily } \\
\text { disassembled. }\end{array}$ & \\
\hline \multirow[t]{2}{*}{9} & \multirow{2}{*}{$\begin{array}{l}\text { Appropriate } \\
\text { site } \\
\text { development }\end{array}$} & $\begin{array}{l}\text { Percentage of basic } \\
\text { green area. }\end{array}$ & 46 \\
\hline & & $\begin{array}{l}\text { Placing sustainable } \\
\text { building project } \\
\text { within easy access } \\
\text { of public facilities. }\end{array}$ & 46,47 \\
\hline \multicolumn{4}{|c|}{ Dimension: Product Safety } \\
\hline \multirow[t]{3}{*}{10} & \multirow[t]{3}{*}{$\begin{array}{l}\text { Occupational } \\
\text { health and } \\
\text { safety }\end{array}$} & $\begin{array}{l}\text { There are } \\
\text { emergency } \\
\text { assembly point in } \\
\text { building design. }\end{array}$ & \multirow[t]{3}{*}{50,51} \\
\hline & & $\begin{array}{l}\text { There are } \\
\text { emergency routes } \\
\text { and exits in } \\
\text { building design. }\end{array}$ & \\
\hline & & $\begin{array}{l}\text { There are access to } \\
\text { working spaces for } \\
\text { construction, } \\
\text { cleaning, } \\
\text { maintenance, and }\end{array}$ & \\
\hline
\end{tabular}




\begin{tabular}{|c|c|c|c|}
\hline & & $\begin{array}{l}\text { repairs in building } \\
\text { design. }\end{array}$ & \\
\hline \multirow[t]{5}{*}{11} & \multirow[t]{5}{*}{$\begin{array}{l}\text { Indoor health } \\
\text { and comfort }\end{array}$} & $\begin{array}{l}\text { Minimum height of } \\
\text { ceiling building } \\
\text { from the floor. }\end{array}$ & \multirow[t]{5}{*}{52} \\
\hline & & $\begin{array}{l}\text { Air conditioner or } \\
\text { fan must be } \\
\text { provide if the } \\
\text { indoor climate } \\
\text { estimation }>28^{\circ} \mathrm{C} \text {. }\end{array}$ & \\
\hline & & $\begin{array}{l}\text { Equipment for } \\
\text { humidity } \\
\text { maintenance must } \\
\text { be provide if the } \\
\text { indoor humidity } \\
\text { estimation }<40 \% \\
\text { or }>60 \% \text {. }\end{array}$ & \\
\hline & & $\begin{array}{l}\text { Percentage total } \\
\text { wide of ventilation } \\
\text { from the floor } \\
\text { wide. }\end{array}$ & \\
\hline & & $\begin{array}{l}\text { The design of } \\
\text { nature and artificial } \\
\text { lighting do not } \\
\text { cause glare and } \\
\text { have proper } \\
\text { intensity as the } \\
\text { purpose. }\end{array}$ & \\
\hline \multicolumn{4}{|c|}{ Dimension: Environmental Control } \\
\hline \multirow[t]{3}{*}{12} & \multirow[t]{3}{*}{$\begin{array}{l}\text { Pollution } \\
\text { prevention }\end{array}$} & $\begin{array}{l}\text { Minimize the } \\
\text { different types of } \\
\text { material which } \\
\text { reduces the } \\
\text { complexity and } \\
\text { number of } \\
\text { separation } \\
\text { processes. }\end{array}$ & \multirow[t]{3}{*}{53} \\
\hline & & $\begin{array}{l}\text { Separate the } \\
\text { structure from the } \\
\text { cladding to allow } \\
\text { for increased } \\
\text { adaptability and } \\
\text { separation of non- } \\
\text { structural } \\
\text { deconstruction to } \\
\text { structural } \\
\text { deconstruction. }\end{array}$ & \\
\hline & & $\begin{array}{l}\text { Use bolted, } \\
\text { screwed, and } \\
\text { nailed connections } \\
\text { instead chemical } \\
\text { connections. }\end{array}$ & \\
\hline \multirow[t]{3}{*}{13} & \multirow[t]{3}{*}{$\begin{array}{l}\text { Design support } \\
\text { for energy } \\
\text { efficiency and } \\
\text { conservation }\end{array}$} & $\begin{array}{l}\text { Use sun shading or } \\
\text { another medium to } \\
\text { reduce energy for } \\
\text { air conditioning. }\end{array}$ & 46 \\
\hline & & $\begin{array}{l}\text { Use mirror ducts or } \\
\text { light shelves to } \\
\text { reduce energy for } \\
\text { artificial lighting. }\end{array}$ & \multirow[t]{2}{*}{46} \\
\hline & & Use solar chimney & \\
\hline
\end{tabular}

\begin{tabular}{|c|c|c|c|}
\hline & & $\begin{array}{l}\text { ventilation, cross } \\
\text { ventilation, or } \\
\text { another ventilation } \\
\text { system for better } \\
\text { air circulation }\end{array}$ & \\
\hline \multirow[t]{4}{*}{14} & \multirow[t]{4}{*}{$\begin{array}{l}\text { Design support } \\
\text { for } \quad \text { water } \\
\text { conservation }\end{array}$} & $\begin{array}{l}\text { Project design shall } \\
\text { include soil } \\
\text { analysis and } \\
\text { specification } \\
\text { appropriate to the } \\
\text { geographic region } \\
\text { (include landscape } \\
\text { planting selection) } \\
\text { to maximize water } \\
\text { retention. }\end{array}$ & 54 \\
\hline & & $\begin{array}{l}\text { Design of rain } \\
\text { water harvesting } \\
\text { system must } \\
\text { consider the } \\
\text { location, filters, } \\
\text { harvesting area, } \\
\text { maintenance, and } \\
\text { integration with } \\
\text { building plumbing. }\end{array}$ & 55,56 \\
\hline & & $\begin{array}{l}\text { Make a proper } \\
\text { design of grey } \\
\text { water system for } \\
\text { toilets flushing and } \\
\text { irrigation. }\end{array}$ & \multirow[t]{2}{*}{55} \\
\hline & & $\begin{array}{l}\text { Setting water } \\
\text { pressure in order to } \\
\text { optimize water } \\
\text { flow rate of taps } \\
\text { and showers. }\end{array}$ & \\
\hline \multirow[t]{2}{*}{15} & \multirow[t]{2}{*}{$\begin{array}{l}\text { Material } \\
\text { resource and } \\
\text { recycle }\end{array}$} & $\begin{array}{l}\text { Use high quality } \\
\text { reused materials } \\
\text { that encourage the } \\
\text { markets for the } \\
\text { reclamation of } \\
\text { materials. }\end{array}$ & \multirow[t]{2}{*}{47,48} \\
\hline & & $\begin{array}{l}\text { Avoid composite } \\
\text { materials and make } \\
\text { inseparable product } \\
\text { from the same } \\
\text { materials that are } \\
\text { then easier to } \\
\text { recycle. }\end{array}$ & \\
\hline \multicolumn{4}{|c|}{ Dimension: Building and Environment Management } \\
\hline \multirow[t]{2}{*}{16} & \multirow[t]{2}{*}{$\begin{array}{l}\text { Environment } \\
\text { collaboration }\end{array}$} & $\begin{array}{l}\text { Conducting joint } \\
\text { planning to } \\
\text { anticipate and } \\
\text { resolve } \\
\text { environmental } \\
\text { related problems. }\end{array}$ & \multirow[t]{2}{*}{$57,58,59$} \\
\hline & & $\begin{array}{l}\text { Making joint } \\
\text { decisions about } \\
\text { ways to reduce the } \\
\text { environmental } \\
\text { impact of } \\
\text { construction } \\
\text { activities. }\end{array}$ & \\
\hline
\end{tabular}




\begin{tabular}{|l|l|l|l|}
\hline 17 & $\begin{array}{l}\text { Environment } \\
\text { assessment } \\
\text { (AMDAL) }\end{array}$ & $\begin{array}{l}\text { Availability of } \\
\text { AMDAL document }\end{array}$ & 46 \\
\hline
\end{tabular}

\section{Discussion}

The application of the GSCM concept in construction requires continuity and relevance to various processes in the project life cycle. In the phase of green initiation and green design, the role of owner and design consultant is the key of the Green concept in construction projects. Green initiation and green design are different phases, so they have different green concept indicators.

In the green initiation phase, the owner plays a very dominant role in determining the application of GSCM. The owner must have the insight and ultimate goal for the Green concept, because without it, this a very small opportunity to apply the green concept. In this phase, the output is the document of Feasibility Study (FS). In the FS document, several feasibility analyses such as technical, costs, investment, and environmental studies are expected to be based on the Green concept.

In the green design phase, consultant of design are the parties most instrumental in determining GSCM's application. In preparation of planning documents or Detail Engineering Design, it is expected to be based on the green concept.

GSCM indicators in both phases can be used as references in drawing up Green concepts from the beginning of the phase in the project life cycle. There are 9 indicators of Green Initiation and 40 indicators of Green Design to support GSCM in construction project.

In the application of GSCM in construction, the owner is the main driver. Phase of green initiation is the initial phase and plays a very vital role because it will be followed by the next phase. The owner becomes the main stakeholder who initiates the philosophy or value that will be applied when the project is built or implemented in the construction. The role of the consultant planner is also a critical point in the selection of design concepts and the selection of materials suitable for the Green concept.

\section{Conclusion}

Based on the results of the study, the application of GSCM in construction projects was determined by 9 indicators in the green initiation phase and 40 indicators in the green design phase. The success of green concept in construction project is very determined from these two phases as the beginning of the process, and the most important parties are the owners and design consultants. The further research could develop indicators for Green Material Management, Green Construction, and Green Operation and Maintenance which linkage to Green Initiation and Green Design.

\section{Akcnoledgement}

This research was financially supported by DRPM of The Ministry of Research, Technology and Higher Education, Indonesia through PDUPT Grant 2019

\section{References}

1. M. Chandrakanthi, P. Hettiaratchi, B. Prado, J. Ruwanpura, Proc Winter Simulation Confr (2002), 1771-1777.

2. L.L. Ekanayake, G. Ofori, Build and Env (2004), 39(7), 851-861.

3. L.Y. Shen, V.W.Y. Tam, C.M. Tam, D. Drew, J. Constr. Eng. Manage. (2004), 130(4), 472-481.

4. S.K. Srivastava, Int J Manag Rev (2007), 9(1), 53-80.

5. S. Balasubramanian, V. Shukla, Prod Planning \& Control (2017), 28(14), 1116-1138.

6. J. Linton, R. Klassen, V. Jayaraman, J. Oper. Man. (2007), 25(1), 1075-82.

7. Q. Zhu, J. Sarkis, J. Clean Prod. (2006), 14, 472-486.

8. B.M. Beamon, Logis. Inf. Manage (1999), 12(4), 332-342.

9. M. Ghobakhloo, S.H. Tang, N. Zulkifli, M. Ariffin, Int. J. Innov. Manage. Tech (2013), 14(1), 86-89.

10. T.A. Chin, H.H. Tat, Z. Sulaiman, Procedia CIRP ( 2015 ), 26, 695-699.

11. R. Geng, S.A. Mansouri, E. Aktas. Int. J. Prod Econ (2017), 183, 245-258.

12. S.-H. Chun, H.J. Hwang, Y.-H. Byun, Procedia-Soc Behv Sci (2015). 186, 507-512.

13. A.J.G. Silvius, M. Kampinga, S. Paniagua, H. Mooi. Int. J. Proj Man (2017), 35, 1133-1150.

14. N.A. Kartam. J. Constr. Eng. Manage. (1996), 122(1), 14-21.

15. W.R. Ducan, Project Management Institute, PA 19073-3299 USA, (1996).

16. G.D. Oberlender, McGraw-Hill, Boston. (2000).

17. F.N. Rasmussen, T. Malmqvist, A. Moncaster, A.H. Wiberg, H. Birgisdóttir, Energy and Buildings, (2017).

18. J. Giesekam, J. R. Barrett, P. Taylor, A. Owen, Energy and Buildings, (2014).

19. G. Efstratios, M. Alice, UK case study World SB4, Bancelona. (2014).

20. Q. Zhu, J. Sarkis, K. Lai, Int. J. Prod Econ (2008), 111, pp 261-273.

21. P. Dadhich, A. Genovese, N. Kumar, A. Acquaye, Int. J. Prod Econ (2015), 164, 271-284.

22. O. Ortiz, F. Castells, G. Sonnemann, Constr Build Materials (2009), 23(1), 28-39.

23. Q. Shi, J. Zuo, R. Huang, J. Huang, S. Pullen, S. Habitat international (2013), 40, 1-8.

24. M.A. Wibowo, N.U. Handayani, A. Mustikasari, J of Ind Eng Manage (2018), 11(4), 651-679.

25. A.N.A. Ali, N.A. Jainudin, R. Tawie, I. Jugah, Procedia-Soc Behv Sci (2016), 224, 626-631. 
26. A.O. Olanipekun, A.P.C. Chan, B. Xia, E.E. Ameyaw, Ecol Indicators (2017), 72 268-277.

27. F.M. Halil, N.M. Nasir, A.A. Hassan, A.S. Shukur, Procedia-Soc Behv Sci (2016), 222, 56-64.

28. X. Zhang, L. Shen, Y. Wu, J Clean Prod (2011), 19(2), 157-167.

29. U.G.B. Council, Leadership in energy and environmental design (LEED) (2001).

30. J. Ying-Liu, S. Pheng-Low, X. He, J Tech Manage in China (2012), 7(1), 50-63.

31. T. Hong, C. Koo, J. Kim, M. Lee, K. Jeong, Applied Energy (2015), 155, 671-707.

32. M. Bal, D. Bryde, D. Feron, E. Ochieng, Sustainability (2013), 6, 695-710.

33. B.G. Hwang, J.S. Tan. Sustainable Development (2012), 20(5), 335-349.

34. T. Thipparat, Int Confr on Innov, Manage Serv IPEDR (2011) 14, IACSIT Press, Singapore.

35. P. Grover, IOSR Journal of Business and Management (2015), 17, 62-69.

36. M. Sun, P.W.H. Chung, S. Senaratne, A. Hamalawi, Eng Phy Sci Res Council (EPSRC) (2004).

37. D. Braha, O. Maimon, IEEE Trans on Sys, Man, Cyber-Part A: Sys Hum (1998), 28(4), 527-535.

38. E.B. Anil, G. Unal, O. Kurc, J Comp in Civil Eng (2012), 26, 465-477.

39. D.F. Fuadie, Y. Rahmawati, C. Utomo, The 3rd Int Confr on Civil Eng Res (ICCER) (2017), 284-288.

40. R. Lopez, P.E.D. Love, D.J. Edwards, P.R. Davis, J Perf of Constr Fac (2010), 24(4), 399-408.

41. CDOT. Colorado State Department of Transportation. 2005.

42. Northern Territory Govenrment. Department of Infrastructure, Planning, and Logstics. 2009.
43. US Department of Transportation. Federal Highway Administration. 2010.

44. Y.-H. Chang, P.-H. Huang, T.-F. Chuang, S.-W. Chang, J of Build Eng, (2016), 7, 114-120.

45. W.S. Alaloul, M.S. Liew, N.A.W.A. Zawawi, Alexandria Eng. J. (2016), 55, 2689-2698.

46. Green Building Council Indonesia, (2013).

47. P.O. Akadiri, E.A. Chinyio, P.O. Olomolaiye, Buildings (2012), 2, 126-152.

48. C. Atombo, J.C.K. Dzantor, A.A. Agbo, Int J of Const Eng Manage (2015), 4(1), 13-25.

49. A. Ruuska, T. Hakkinen, Buildings (2014), 4, 266294.

50. Safe Work Australia. (2012).

51. J. Whyte, R. Sacks, W. Zhou, A. Haffegee, IOSH Research Committee (2013).

52. Peraturan Menteri Kesehatan Republik Indonesia Nomor 70 Tahun 2016 Tentang Standar dan Persyaratan Kesehatan Lingkungan Kerja Industri.

53. P. Crowther, Royal Australian Institute of Architects/BDP, (1999).

54. State Energy Conservation Office, Texas Comptroller of Public Accounts (2016).

55. J. Gibberd, CSIR Built Environment. (2009).

56. O. Das, P. Bera, S. Moulick, IJRET: Int J of Res in Eng Tech (2015), 04(13), 75-79.

57. M.G. Kim, C. Woo, J.J. Rho, Y. Chung, (2016). Sustainability (2016), 8, 82.

58. M. Pero, A. Moretto, E. Bottani, B. Bigliardi, (2017). Sustainability (2017), 9, 125.

59. S. Vachon, R.D. Klassen, Int J Prod Econ (2008), 111, 299-315 